\title{
Structural Audit of 40 year old Silo
}

\author{
Akshay Shivankar', Dr. K. R. Dabhekar', P. B. Patil ${ }^{3}$, Dr. I.P.Khedikar ${ }^{4}$, Dr.D.P.Mase ${ }^{5}$ \\ PG Student, Structural Engineering, G H Raisoni College of Engineering, Nagpur, India ${ }^{1}$ \\ Asst Professor, Civil Engineering Department, G H Raisoni College of Engineering Nagpur, India ${ }^{2}$ \\ Asst Professor, Civil Engineering Department, G H Raisoni College of Engineering Nagpur, India ${ }^{3}$ \\ Asst Professor, Civil Engineering Department, G H Raisoni College of Engineering Nagpur, India ${ }^{4}$ \\ Director of P T MASE \& ASSOCIATES, Nagpur, Maharashtra India ${ }^{5}$
}

\section{Article Info}

Volume 8 Issue 2

Page Number: 222-230

\section{Publication Issue :}

March-April-2021

\section{Article History}

Received : 20 Dec 2020

Accepted : 20 March 2021

Published : 29 March 2021

\section{ABSTRACT}

In India structural stability of old structures and fire protection and safety is one of the most common issues. because the strength of old structures get reduced in due course of your time it generate structural flaws like material diminution, unexpected over loading, structural scarcity or physical damages and if further use of such damaged structure it's getting to leads to severe loss of human life and public property. As Structural Audit of old structure is obligatory as per municipal authorities and Government of Gujarat has made "Structural Audit" of all old structures compulsory. the most objective of present work is to adopt Structural Auditing of 40 years old silo which is situated at Somnath (Gujrat) with Schmidt's Hammer Test, Ultra Sonic Pulse Velocity Test, Cover Meter Test, Half-cell test, $\mathrm{pH}$ test including Visual Inspection and assessing the stableness and safety of the structure to confront to for its remaining life by diagnosis and root explanation for the issues with remedial measures. Based upon above test is observed that the attribute of concrete is medium at maximum locations and Doubtful at few locations, corrosion has started in reinforcement and well within the suitable limit. Hence, it's recommended to repair damaged areas as per the methodology, specifications and locations.

Keywords : PH test, Half-cell test, Ultrasonic pulse velocity test, Rebound hammer test, NDT method, Structural Assessment Program

\section{INTRODUCTION}

Structures are assemblies of load carrying members capable of safely transferring the superimposed loads to the foundations. because the structure gets older and older as time goes, during this due course of your time structures have reduced strength thanks to material deterioration, unexpected over loading, structural deficiency or physical damages. If, further use of such deteriorated structure is sustained it's going to cause severe loss of life and property. We all agree that each life is precious and each structure is, in a way, a national asset, therefore, there's need of periodical maintenance and checkup to stop future damages. Structural Audit may be a preliminary technical survey of a 
building to guage the strength so on improve its appropriateness, safety, efficiency. The Audit highlights \& investigates all the danger areas, critical areas of the Building and also suggests if building needs immediate attention. The Structural Audit is administered by appointing a Structural Engineer. He examines the structure by visual inspection of the Building and if required the Non Destructive Tests are administered consistent with requirement of structure. the aim of building standard procedures for nondestructive testing (NDT) of concrete structures is to qualify and quantify the fabric properties of in-situ concrete without causing damage. The range of properties which will be assessed using non-destructive techniques is large and includes fundamental parameters of the Concrete like density and coefficient of elasticity additionally to strength. Other properties which may be assessed include concrete surface hardness, Surface absorption and moisture condition also as reinforcement location, cover and corrosion risk. Government of Gujarat has made "Structural Audit" of all old building compulsory as per the great General Development Control Regulations enforcing from 12/10/2017.As per Schedule 17 (Schedule for Maintenance and Inspection for Structural Stability and Fire Safety) and Form 15. Structural Audit is mandatory for all Industrial Structures as per corporation directive and as follows:-

\begin{tabular}{|r|r|}
\hline Age of the Structure & $\begin{array}{r}\text { Structural } \\
\text { Audit } \\
\text { (Com } \\
\text { pulso } \\
\text { ry) }\end{array}$ \\
& Once in 5 \\
years \\
\hline 15 to 30 years & Once in 3 \\
& years \\
\hline Above 30 years & \\
& \\
\hline
\end{tabular}

\section{OBJECTIVES}

The crucial objective of present work is to adopt Structural Auditing of 40 years old silo which is situated at Somnath (Gujrat) with Schmidt's Hammer Test, Ultrasonic Pulse Velocity Test, Cover Meter Test, Half-cell test, $\mathrm{pH}$ test including Visual Inspection And Assessing the stability and safety of the structure to withstand for its remaining life by Diagnosis and root cause of the problems with remedial measures.

\section{METHODOLOGY}

The methodology of the project comprises of four major stages which are as follows:

1. Visual Observation is one among the foremost important step in non-destructive tests. It include as an example, cracks, pop-outs, spalling, disintegration, colour change, weathering, staining, surface blemishes and deficiency of uniformity From Visual Inspection, As an engineer it's duty to collect information which is useful to understand condition of the structure and permit formulization of a subsequent testing programme and suggest reparing methodology.

2. Rebound Hammer Test the tactic is predicated on the principle that the rebound of an elastic mass depends on the surface hardness averse which mass strikes. When the plunger of rebound hammer is pressed on the surface of the concrete, the spring controlled the mass of rebounds, Hence the extent of such rebound depends on the surface hardness of concrete. Rebound are related with the compressive strength of the concrete. The rebound number and index are read from graph provided on rebound hammer along a graduated scale. For finding the measurement, the hammer should be place at right angles to the concrete surface. The test are calculated horizontally on vertical surfaces 
and vertically upwards or downwards on horizontal surfaces.

\section{Rebound Criteria for Quality of Concrete Grading as per (IS 13311 Part II)}

\begin{tabular}{|c|c|}
\hline Average Rebound & Quality of Concrete \\
\hline$>40$ & $\begin{array}{c}\text { Very Good hard } \\
\text { layer }\end{array}$ \\
\hline $30-40$ & Good \\
\hline $20-30$ & Fair \\
\hline$<20$ & Poor concrete \\
\hline 0 & Delaminated \\
\hline
\end{tabular}

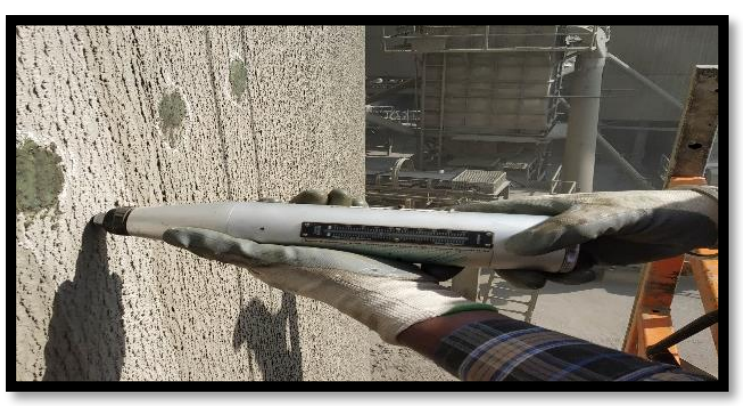

Fig 1. Rebound Hammer

3. Ultrasonic Pulse Velocity Test A throb of longitudinal vibrations is produced by an electroacoustical transducer, which is held in touch with one surface of the concrete under test. When the throb generated is transmitted into the concrete from the transducer employing a liquid coupling material like grease or cellulose paste, it undergoes multiple reflections at the boundaries of the varied material phases within the concrete, a posh system of stress waves develops, which include both longitudinal and shear waves, and propagates through the concrete. The primary waves to achieve the receiving transducer are the longitudinal waves, which are converted into an electrical signal by a second transducer. Electronic timing circuits enable the transit time $\mathrm{T}$ of the pulse to be measured and the pulse velocity is determined by path length by transit Time. Pulse
Velocity in concrete will be represented in $\mathrm{Km} / \mathrm{sec}$ or $\mathrm{M} / \mathrm{s}$. The instrument indicates the time taken for the earliest a part of the heart beat to succeed in the receiving transducer measured from the time it leaves from an appropriate point on the surface of the material.

The pulse velocity is determined by the equation: -

$$
\text { Pulse Velocity }=\frac{\text { Path }}{\text { Transit }} \frac{\text { Length }}{\text { Time }}
$$

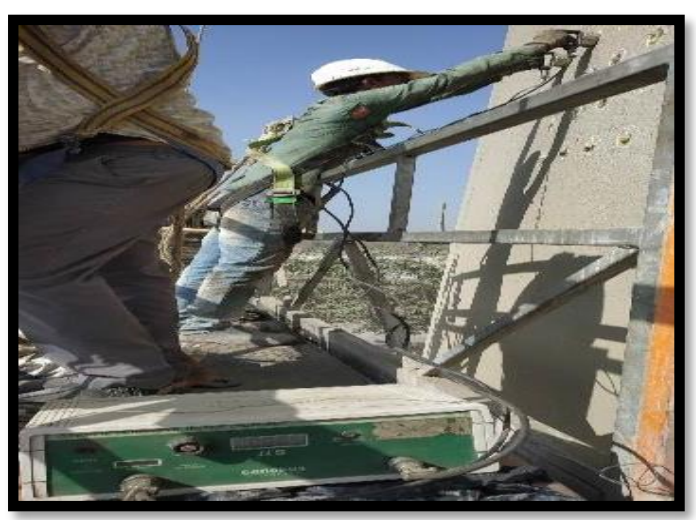

Fig 2. U.P.V Test

The instrument indicates the time taken for the earliest a part of the heart beat to succeed in the receiving transducer measured from the time it leaves from an appropriate point on the surface of the material.

The path length and transit time are measured to determine the pulse velocity. The velocity of longitudinal pulse in elastic solids. It are often shown that the speed $\mathrm{V}$ of pulse of longitudinal ultrasonic vibration traveling in an elastic solid is given by:

$$
\mathrm{V}^{2}=\mathrm{E}(1-\mu) / \mathrm{p}(1+\mu)(1-2 \mu) \text { (B.S. } 1881 \text { Part }
$$

203 - 1986)

Where, $\mathrm{E}$ is the dynamic elasticity modulus

$\mathrm{P}$ is the density

$\mu$ is the Poisson's ratio.

As per IS 516 (Part 5/Sec 1):2018 Table 1 velocity criterion for concrete Quality Grading 
Velocity Criteria for Quality of Concrete Grading

\begin{tabular}{|c|c|}
\hline Pulse Velocity & $\begin{array}{c}\text { Quality of } \\
\text { Concrete }\end{array}$ \\
\hline Above $4.5 \mathrm{Km} / \mathrm{Sec}$ & Excellent \\
\hline $3.5-4.5 \mathrm{Km} / \mathrm{Sec}$ & Good \\
\hline $3.0-3.5 \mathrm{Km} / \mathrm{Sec}$ & Satisfactory \\
\hline Below $3.0 \mathrm{Km} / \mathrm{Sec}$ & Doubtful \\
\hline
\end{tabular}

Pulses aren't transmitted through large air voids during a material and if such a void lies directly within the pulse path the instrument will indicate the time taken by the heart beat which followed quickest route. It's thus possible to detect large voids when grid of pulse velocity measurement is formed over a neighborhood during which voids are located.

The pulse velocity method of testing could even be applied to the testing of plain reinforced and prestressed concrete whether it's pre-cast or cast in-situ. The measurement of pulse velocity could also be wont to determine. The homogeneity, void cracks, changes in concrete such as chemical attack, quality, of concrete.

4. Half Cell Test- The half-cell potential method measurements normally involves measuring the potential of an embedded reinforcing bar relative to a reference half-cell placed on the concrete surface. The half-cell is typically a copper/copper sulphate or silver/silver chloride cell but other combinations are used. The concrete functions as an electrolyte and therefore the risk of corrosion of the reinforcement within the immediate region of the test location could also be related empirically to the measured electric potential difference. In some circumstances, useful measurements are often obtained between two half-cells on the concrete surface. ASTM C876 91 gives a typical Test Method for Half-Cell Potentials of Uncoated Reinforcing Steel in Concrete. Risk of Corrosion Against Potential
Difference Reading. This technique is presumably to be used for assessment of the sturdiness of reinforced concrete members where reinforcement corrosion is suspected.

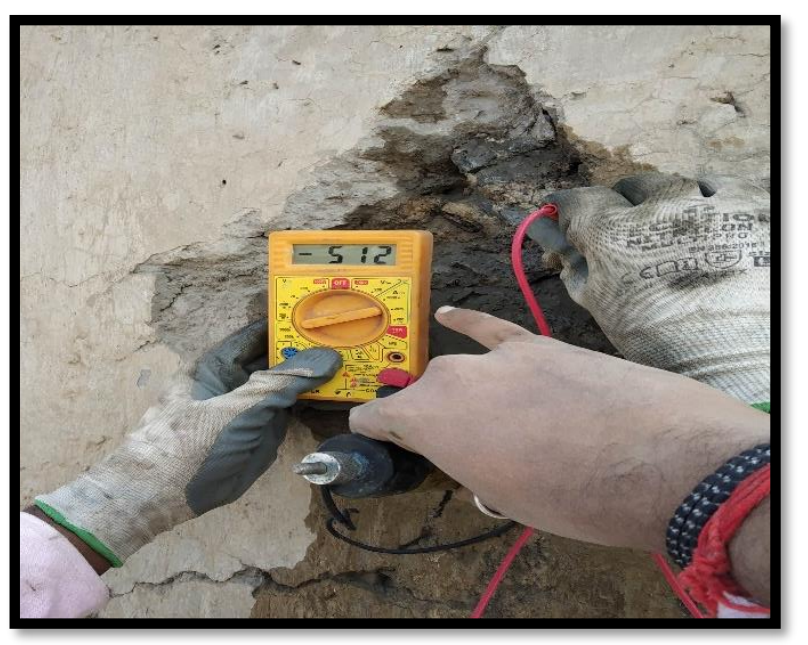

Fig No.-3.Half cell test

\section{Corrosion Criteria}

\begin{tabular}{|c|c|}
\hline $\begin{array}{c}\text { Half-cell potential (mv) } \\
\text { relative to } \mathrm{Cu}-\mathrm{Cu} \\
\text { sulphate Ref. Electrode }\end{array}$ & $\begin{array}{c}\text { \% chance of corrosion } \\
\text { activity }\end{array}$ \\
\hline Less than -200 & $10 \%$ \\
\hline Between -200 to -350 & $50 \%$ (uncertain) \\
\hline Above -350 & $90 \%$ \\
\hline
\end{tabular}

5. Cover Meter Test a cover meter is a device designed specifically for determining the "cover" to reinforcement bars in concrete. Location of embedded rebar's \& estimation of size of embedded rebar's. Cover is defined as being the distance from a given surface of a concrete element to the nearest part of a reinforcement bar or other embedded item. Knowing the diameter of the bar and their location is essential to understand the bar spacing and their placement, in existing structures where there are not any structural drawings available. The cover thickness is significant from the aim of view of estimation of initiation of corrosion. Cover meter is significant to form sure longer life for the structure. 


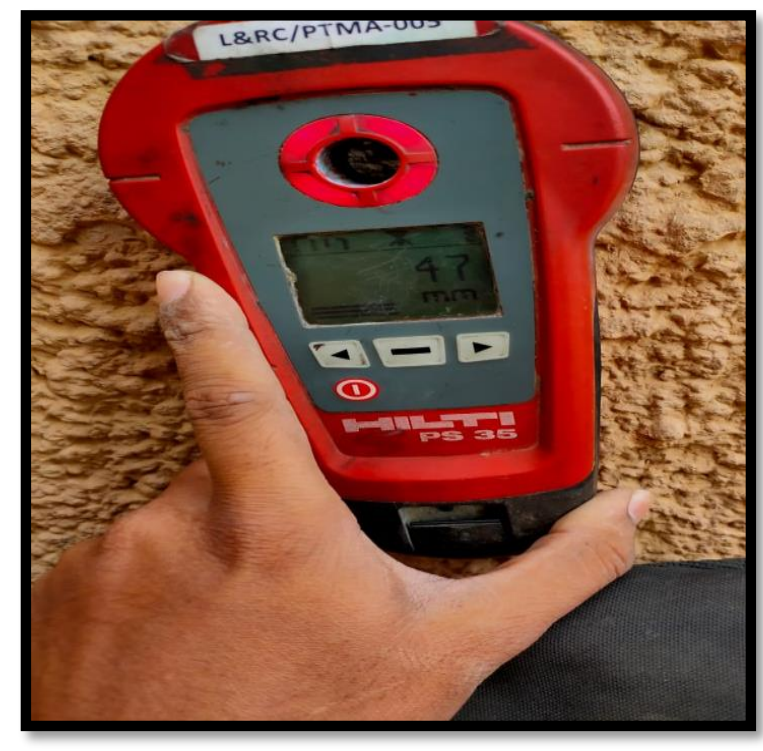

Fig No.4-Cover merer

6. $\mathrm{pH}$ Test when the $\mathrm{CO} 2$ in atmosphere within the presence of moisture reacts with hydrated cement, Carbonation of concrete occurs. Carbonation process is additionally called as depassivation. Carbonation of concrete is related to the corrosion of steel reinforcement and with shrinkage. The method to establish the extent of carbonation in concrete by applying a solution of $15 \mathrm{mg}$ Phenolphthalein \& $10 \mathrm{ml}$ Ethanol diluted in $50 \mathrm{ml}$ of distilled water to a fresh fracture surface of concrete. The change of Pink color of concrete indicate carbonation free concrete while the uncolored indicated carbonation. The $\mathrm{pH}$ of concrete lowers when the carbon dioxide in the air comes in contact with concrete, the process is called carbonation. A standard $\mathrm{pH}$ meter is used to measure the $\mathrm{pH}$ of concrete. If $\mathrm{pH}$ value between 7 to 9 Concrete stats to break down and $\mathrm{pH}$ of the concrete below 8.6, suggesting carbonation.
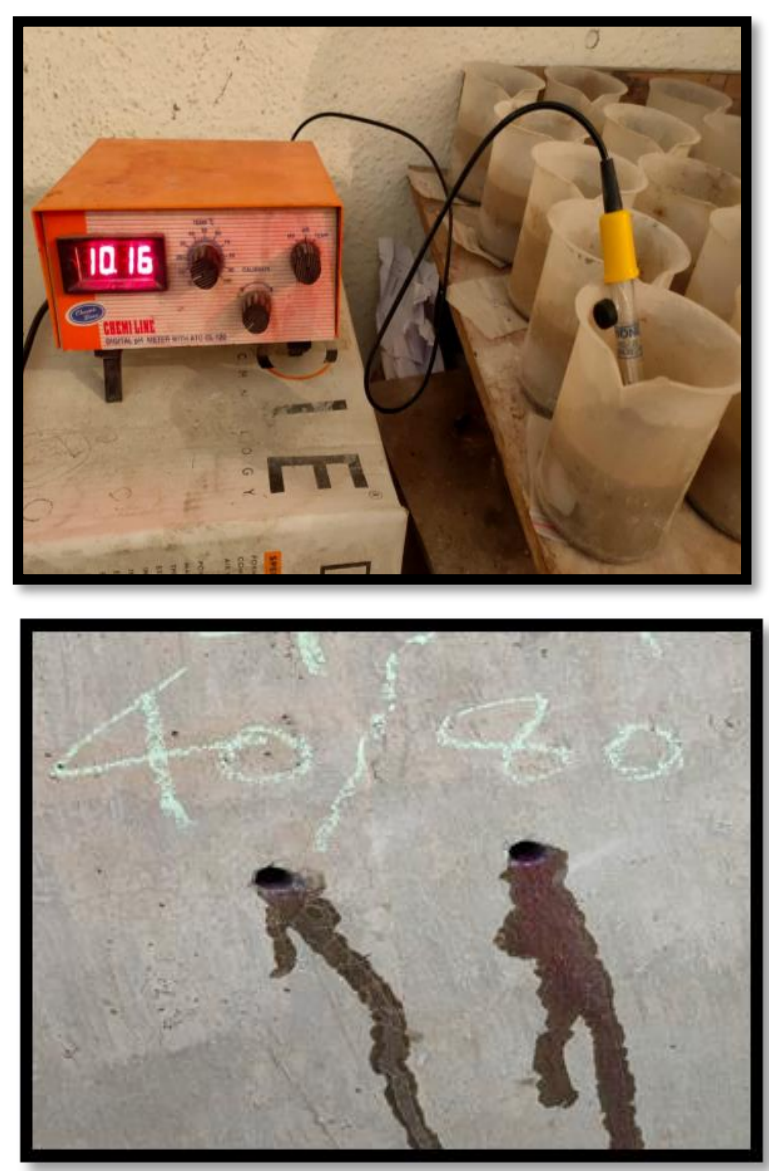

Fig No.-5.PH TEST

\section{Results}

\begin{tabular}{|c|c|c|c|c|}
\hline Sr.No. & Particulars & Rebound No & $\begin{array}{c}\text { Averag } \\
\text { e }\end{array}$ & $\begin{array}{c}\text { Probable } \\
\text { Compressive } \\
\left.\text { Strength (N/mm }{ }^{2}\right)\end{array}$ \\
\hline Raw Mill Silo & $\begin{array}{c}\text { West Side At } 40 \\
\text { Mtr Level }\end{array}$ & $\begin{array}{c}38,32,34,36,32,40,34,36,34,40,38 \\
, 36\end{array}$ & 36 & 37 \\
\hline 2. & $\begin{array}{c}\text { West Side At 30 } \\
\text { Mtr Level }\end{array}$ & $\begin{array}{c}30,32,36,34,36,38,32,34,36,32,36 \\
, 34\end{array}$ & 34 & 34 \\
\hline
\end{tabular}




\begin{tabular}{|c|c|c|c|c|}
\hline 3. & $\begin{array}{c}\text { West Side At 20 } \\
\text { Mtr Level }\end{array}$ & $\begin{array}{c}30,36,32,38,34,40,38,36,34,38,38 \\
, 36\end{array}$ & 36 & 37 \\
\hline 4. & $\begin{array}{c}\text { West Side At } 10 \\
\text { Mtr Level }\end{array}$ & $\begin{array}{c}32,30,26,32,32,28,26,32,36,32,30 \\
, 28\end{array}$ & 30 & 27 \\
\hline
\end{tabular}

Table-1.Rebond Hammer Test Results

Table-2. U.P.V Results

\begin{tabular}{|c|c|c|c|c|c|c|c|}
\hline $\begin{array}{l}\text { Sr.No } \\
\text { • }\end{array}$ & Description & Particular & $\begin{array}{l}\text { Transit } \\
\text { time in } \\
\text { Micro } \\
\text { Seconds } \\
\text { (T) }\end{array}$ & $\begin{array}{l}\text { Path } \\
\text { length } \\
(\mathrm{L}) \\
(\mathrm{mm})\end{array}$ & $\begin{array}{l}\text { Velocity } \\
\mathrm{V}=(\mathrm{L} / \mathrm{T}) \\
\text { (in } \\
\mathrm{KM} / \mathrm{Sec})\end{array}$ & $\begin{array}{l}\text { Factored } \\
\text { value of } \\
\text { U.P.V. in } \\
\mathrm{Km} / \mathrm{sec}\end{array}$ & Remark \\
\hline \multicolumn{8}{|c|}{ Raw Mill Silo } \\
\hline \multirow{3}{*}{1.} & \multirow[t]{3}{*}{$\begin{array}{l}\text { West Side At } \\
40 \text { Mtr Level }\end{array}$} & Indirect & 106 & 200 & 1.89 & 2.89 & Doubtful \\
\hline & & Indirect & 112 & 200 & 1.79 & 2.79 & Doubtful \\
\hline & & Indirect & 119 & 200 & 1.68 & 2.68 & Doubtful \\
\hline \multirow{3}{*}{2.} & \multirow[t]{3}{*}{$\begin{array}{l}\text { West Side At } \\
30 \text { Mtr Level }\end{array}$} & Indirect & 93 & 200 & 2.15 & 3.15 & Medium \\
\hline & & Indirect & 98 & 200 & 2.04 & 3.04 & Medium \\
\hline & & Indirect & 96 & 200 & 2.08 & 3.08 & Medium \\
\hline \multirow{3}{*}{3.} & \multirow[t]{3}{*}{$\begin{array}{l}\text { West Side At } \\
20 \mathrm{Mtr} \text { Level }\end{array}$} & Indirect & 97 & 200 & 2.06 & 3.06 & Medium \\
\hline & & Indirect & 98 & 200 & 2.04 & 3.04 & Medium \\
\hline & & Indirect & 103 & 200 & 1.94 & 2.94 & Doubtful \\
\hline \multirow{3}{*}{4.} & \multirow[t]{3}{*}{$\begin{array}{l}\text { West Side At } \\
10 \text { Mtr Level }\end{array}$} & Indirect & 95 & 200 & 2.11 & 3.11 & Medium \\
\hline & & Indirect & 91 & 200 & 2.20 & 3.20 & Medium \\
\hline & & Indirect & 106 & 200 & 1.89 & 2.89 & Doubtful \\
\hline
\end{tabular}




\begin{tabular}{|c|c|c|}
\hline \multicolumn{3}{|l|}{ Raw Mill Silo } \\
\hline SR. NO. & PARTICULARS & HALF CELL \\
\hline \multirow{10}{*}{1.} & \multirow{10}{*}{$\begin{array}{c}\text { West Side At } 25 \\
\text { Mtr Level }\end{array}$} & -345 \\
\hline & & -376 \\
\hline & & -402 \\
\hline & & -366 \\
\hline & & -365 \\
\hline & & -389 \\
\hline & & -432 \\
\hline & & -378 \\
\hline & & -405 \\
\hline & & -289 \\
\hline
\end{tabular}

Table-3. Half Cell Results

Note-Below -250 NO Corrosion, $-250 \mathrm{mv}$ to $-350 \mathrm{mv}$ Possibility of Corrosion, Above $-350 \mathrm{mv}$ Active corrosion.

Table-4.Cover Meter Test Results

\begin{tabular}{|c|c|c|}
\hline SR.NO. & DESCRIPTION & $\begin{array}{c}\text { COVER TO THE REINFORCEMENT IN( } \\
M M)\end{array}$ \\
\hline \multicolumn{3}{|l|}{ Raw Mill Silo } \\
\hline 1 & $\begin{array}{l}\text { West Side At } 40 \text { Mtr } \\
\text { Level }\end{array}$ & $59,66,67,68,69,102$ \\
\hline 2. & $\begin{array}{l}\text { West Side At } 30 \text { Mtr } \\
\text { Level }\end{array}$ & $54,69,59,55,68,69$ \\
\hline 3. & $\begin{array}{l}\text { West Side At } 20 \text { Mtr } \\
\text { Level }\end{array}$ & $77,74,69,79,67,66$ \\
\hline 4. & $\begin{array}{l}\text { West Side At } 10 \mathrm{Mtr} \\
\text { Level }\end{array}$ & $63,66,67,102,79,77$ \\
\hline
\end{tabular}


Table-5.PH Test Results

\begin{tabular}{|c|c|c|c|c|}
\hline \multirow{2}{*}{$\begin{array}{l}\text { SR. } \\
\text { NO. }\end{array}$} & \multirow[t]{2}{*}{ PARTICULARS } & \multicolumn{2}{|c|}{ POTENTIAL MV } & \multirow[t]{2}{*}{$\mathrm{pH}$} \\
\hline & & $40 \mathrm{~mm}$ & $80 \mathrm{~mm}$ & \\
\hline \multicolumn{5}{|c|}{ Raw Mill Silo } \\
\hline 1. & West Side At 40 Mtr Level & -261 & -253 & 11.95to12.42 \\
\hline 2. & West Side At 30 Mtr Level & -242 & -256 & 11.91to11.96 \\
\hline 3. & West Side At 20 Mtr Level & -226 & -254 & 11.63to12.98 \\
\hline 4. & West Side At 10 Mtr Level & -230 & -259 & 11.95to12.42 \\
\hline
\end{tabular}

\section{Pie Charts Shows Results-}

\section{Rebound Hammer Test Results}

$>40$-very good, 30-40-Good, 20-30-Fair, $<20$-Poor Concrete

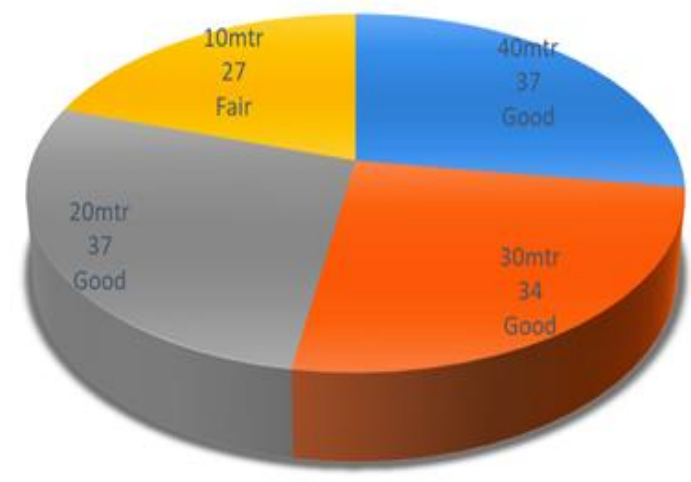

$=1$ st Qtr $=2 \mathrm{nd} \mathrm{Qtr}=3 \mathrm{rdQ}$ tr $=4$ th Qtr

\section{Half Cell Test Result}

Below - 250 NO Corrosion, -250mv to -350mv Possibility

of Corrosion, Above - $350 \mathrm{mv}$ Active corrosion

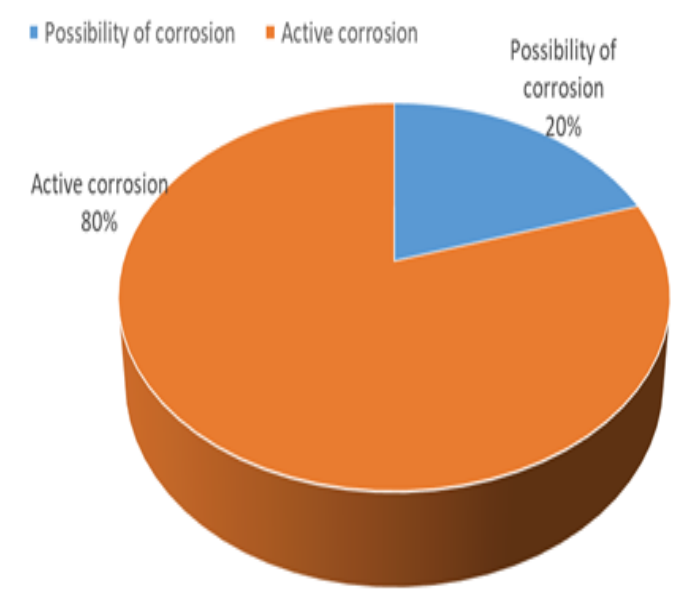

\section{U.P.V Test Results}

$>$ 4.5-Excellent,3.5-4.5-Good,3.0-3.5-

Medium, <3.0-Doubtful

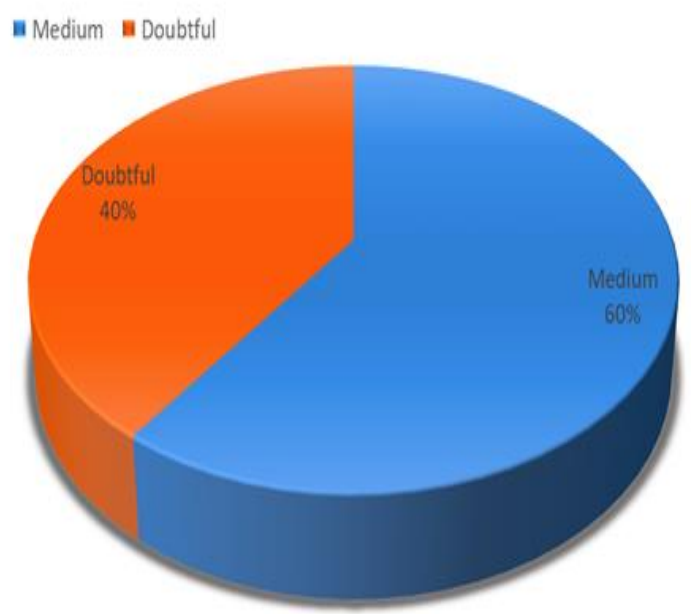

4. PH Test Result

PH Above 8.6 Suggesting Carbonation 


\section{CONCLUSION}

Based on all Nondestructive test results R.C.C silo needs structural strengthening and repairing work with help of injection grouting and polymer concreting work and rebaring whenever need and some places need micro concreting and Anodic protection for steel corrosion and for paint anti corrosive paint which side reinforcement exposed two coat of anticorrosive paint and polymer concreting is required.

\section{REFERENCES}

[1]. Nondestructive testing of concrete method of test (Ultra Sonic Pulse Velocity) IS 13311 (Part I) 1992

[2]. Schmidt hammer IS 13311 (Part II) 1992

[3]. Code of practice for reinforced concrete IS 4562000

[4]. Method of tests for strength of concrete IS 5161959

[5]. Strength evaluation of existing concrete building report by ACI committee 437 ACI437R-91

[6]. Corrosion of metal in concrete Part I report by ACI committee 222 ACI-222R-89

[7]. $\mathrm{pH}$ value B.S. 5741-1991

[8]. Dr. Dilip P. Mase, A Case Study of Structural Assessment and Auditing report for Residential Building Nagpur (Maharashtra), August 2018.

[9]. BS 1881: Part 201: 1986 British Standard Testing concrete Part 201. Guide to the use of nondestructive methods of test for hardened concrete.

\section{Cite this article as :}

Akshay Shivankar, Dr. K. R. Dabhekar, P. B. Patil, Dr. I. P. Khedikar, Dr. D. P. Mase, " Structural Audit of 40 year old Silo, International Journal of Scientific Research in Science, Engineering and Technology(IJSRSET), Print ISSN : 2395-1990, Online ISSN : 2394-4099, Volume 8, Issue 2, pp.222-230, March-April-2021. Available at doi : https://doi.org/10.32628/IJSRSET218260 Journal URL : https://ijsrset.com/IJSRSET218260 